\begin{tabular}{lll} 
KULTURA & $\begin{array}{l}\text { POLSKA A KADEMIA NAUK } \\
\text { KOMITET SOCJOLOGII }\end{array}$ & ISSN 0023-5172 \\
I & $\begin{array}{l}\text { INSTYTUT STUDIÓW POLITYCZNYCH } \\
\text { SPOLECLENSTWO nr } 2\end{array}$ & WIDZIANE W MIEŚCIE \\
\hline
\end{tabular}
A $\mathrm{R}$
R $\quad \mathrm{T} \quad \mathrm{Y}$
K
U $\quad \begin{array}{ll}\mathbf{Y} & \mathrm{Y}\end{array}$
I
$\begin{array}{llllllll}\mathbf{R} & \mathbf{O} & \mathbf{Z} & \mathbf{P} & \mathbf{R} & \mathrm{A} & \mathrm{W} & \mathrm{Y}\end{array}$

WALDEMAR KULIGOWSKI

Uniwersytet im. Adama Mickiewicza w Poznaniu

\title{
„FUCK THE CONTEXT!” \\ KRYTYCZNY DYSKURS REGIONALNY W KONTEKŚCIE BADAŃ FORESIGHT
}

Region nie miałby już prawa istnieć, gdyby uwzględnić wagę i częstotliwość krytyki, jaka była kierowana pod jego adresem. Przy czym nie chodzi tylko o przekonanie, w myśl którego granice, treść i reguły naszego świata są wyznaczane przez konwencje językowe (np. redefinicja długu publicznego przez Kongres USA w 2014 roku oddaliła widmo bankructwa tego państwa). Idea regionu została bowiem podważona i zdewaluowana $z$ poważnych pozycji naukowych: jej zasadność zakwestionowano w dyskursie dyscyplinarnym architektury (Frampton, Koolhaas, Ibelings), historii sztuki (DaCosta Kauffman, Piotrowski), antropologii społecznej (Gupta, Ferguson, Malkki, Bhabha) oraz studiów (nomen omen) regionalnych itp. Chciałbym tu najpierw dokonać przeglądu i podsumowania tej krytyki, a następnie skupić się na wybranym przykładzie współczesnego dyskursu władzy, w którym koncepcja regionu nadal jest używana i odpowiada przyjmowanemu implicite założeniu o naturalności różnicy oraz podziału terytorialno-kulturowego. Przykładem tym będą działania w ramach projektu badawczego „Foresight Regionalny dla Wielkopolski" ${ }^{1}$.

Adres do korespondencji: walkul@amu.edu.pl

${ }^{1}$ Były to badania przeprowadzone w latach 2009-2011 przez Urząd Marszałkowski Województwa Wielkopolskiego w ramach projektu „Budowa Wielkopolskiego Systemu Innowacji”. Inaczej niż $\mathrm{w}$ podobnych przypadkach nacisk nie został położony na projekty infrastrukturalne, ale raczej na myślenie w kategoriach rozwoju społecznego. Szersze informacje zob. dalej w tekście. 


\section{„FUCK THE CONTEXT!”}

Jedna z kluczowych debat współczesnej krytyki architektonicznej dotyczy regionu i lokalności. W różnych wariantach ponawia się dzisiaj pytanie o możliwość współtworzenia tożsamości kulturowej regionu poprzez projektowanie i wznoszenie budynków. W tle tej debaty wciąż trwa niewygasły spór o dziedzictwo modernizmu i jego pochodnych, a przede wszystkim tak zwanego stylu międzynarodowego. Przypomnę, że styl ten kojarzony jest z Le Corbusierem i jego wiarą w zestandaryzowaną technologię prefabrykatów, a wyrażał się najdobitniej $\mathrm{w}$ budowie megaosiedli, projektowanych zgodnie $z$ wytycznymi programami Międzynarodowego Kongresu Nowoczesnej Architektury i Karty Ateńskiej. Architekt stworzył architektoniczną „wielką narrację” modernizmu, opartą na idei domu jako maszyny do życia, w której wygoda i higiena są ważniejsze od „strzępów starej szaty naszych uczuć”, a „[m]iędzy nowoczesnym stanem ducha a dusznym składem wielowiekowych odpadów panuje bolesna niezgodność" (Le Corbusier 2012, s. 307). Jednym z prądów, które otwarcie dezawuują zasadność założeń stylu międzynarodowego, stał się krytyczny regi on ali z m. Jego podstawy zostały przedstawione przez Kennetha Framptona w tekście Towards a Critical Regionalism: Six Points for an Architecture of Resistance (1983). Próbował on zdystansować się wobec dwóch filarów dwudziestowiecznego myślenia o architekturze: zarówno wobec przywołanego już stylu międzynarodowego, jak i nostalgicznego kopiowania form archaicznych i lokalnych. Obie te tendencje Frampton uznawał za szkodliwe dla zachowania i utrwalenia tożsamości miejsc; obie prowadziły bowiem do zaprojektowanej uniformizacji, tyle że przeprowadzanej pod sztandarami odmiennych wartości.

Sceptyczne stanowisko Framptona wobec idei regionu jako określonego zbioru norm (w tym wypadku architektonicznych) i wynikających z nich powinności inni architekci wyrażali w sposób znacznie bardziej dosadny. Do środowiskowej legendy przeszło już hasło „Fuck the context!”. Sformułował je jeden $z$ najbardziej znanych i kontrowersyjnych architektów Rem Koolhaas W manifeście Bigness or the problem of Large z 1993 roku. Koolhaas to zwolennik autonomiczności architektury i architekta, pragnący przywrócić tej profesji etos twórczy, którego istotą jest „plan, klasyczny produkt urbanistyki” (Zaera 1999, s. 30). W takim też duchu należy zapewne odczytywać jego zaczepne hasło - chodzi w nim nie tylko o ucieczkę od kontekstu i jego ograniczeń, ale jeszcze bardziej o uwolnienie się od modernizmu i otwarcie na nowe myślenie o architekturze. Efekty tego nowego myślenia (sam Koolhaas preferuje określenia w rodzaju „zaangażowana praktyka badawcza”) są zaskakujące. W swojej pracy dyplomowej przeniósł on na przykład Mur Berliński w krajobraz miejski Londynu. Głęboko tragiczny obiekt po przeniesieniu z jednej stolicy do drugiej radykalnie zmienił swój sens, stając się elementem sielankowej przestrzeni. Trudno zapewne o bardziej dosadne zerwanie $z$ kontekstem i jakimikolwiek znakami regionalności. 
Dla Koolhaasa był to jednak tylko początek drogi ku krytycznemu regionalizmowi. Jej kolejną odsłoną stał się projekt sali koncertowej w Porto. Architekt postanowił wykorzystać $\mathrm{w}$ tym przypadku projekt domu jednorodzinnego z przedmieść Rotterdamu. Praca polegała przede wszystkim na odpowiednim powiększeniu jego szkieletu. Koolhaas wspomina, że fascynujące było obserwowanie, jak projekt przeznaczony do zupełnie innego miejsca i zgoła odmiennych celów daje się skutecznie przekształcić i przemieścić. Inną konsekwencją hasła „Fuck the context!” jest projekt siedziby chińskiej telewizji państwowej. Jego bazą był koncept wieżowca - emblematyczna, amerykańska struktura, tak bliska admirowanemu przez Koolhaasa „manhatanizmowi”. Ideowy szkielet projektu i związany z nim model modernizacji przeszczepiono oczywiście skądinąd, tworząc budynek, który z powodzeniem mógłby zostać wzniesiony — i pomyślany - jednocześnie na aż trzech kontynentach. Wszelkie lokalne odniesienia i relacje między regionalnym a globalnym zepchnięto tym samym do skansenu czy czegoś na kształt „muzeum regionalnych form” (Moćko 2013, s. 9). Takie świadome praktyki stawiają przed pytaniami o kształt, znaczenie i logikę lokalności oraz regionalności. Czy w globalizującym się świecie przypadkiem nie jest tak, że więcej łączy regiony wydobycia ropy naftowej albo diamentów niż terytoria bezpośrednio sąsiadujące ze sobą, ale pozbawione takiego unifikującego czynnika? A w konsekwencji - czy wszelkie polityki regionalne, zafiksowane na punkcie różnicy i tożsamości, nie przynależą także do przebrzmiałego już modernizmu? Często jest przecież tak, jak zauważa Koolhaas (1999, s. 43), że współczesny regionalizm sprowadza się do aktu „produkcji regionalnych różnic po ich zniesieniu i zniknięciu".

Ważnym w tym kontekście zjawiskiem jest tak zwany supermodernizm. Architektura końca XX wieku — zwłaszcza tworzona przez takie jej ikony, jak Zaha Hadid, Daniel Libeskind, Frank Gehry czy cytowany wyżej Koolhaas — da się ujmować właśnie jako ekspresja supermodernizmu. Pod tym terminem Hans Ibelings (1998) rozumie promocję bezmiejscowych, wolnych od lokalnego kontekstu projektów, w ramach których świat jest tylko czystą, prostą przestrzenią. Najważniejsze walory takiej architektury to jej globalność, neutralność oraz brak uwikłania w formy przedstawiające. Poszukiwania przykładów ignorowania regionu i lokalności na gruncie architektury nie muszą przy tym wcale prowadzić ku manifestom, teoriom i wielkim realizacjom „starchitektów”. Architektoniczny krajobraz współczesnej Polski reprezentuje przecież podobne podejście, tyle że praktykowane w bardziej wulgarny sposób. Wystarczy wskazać na dominujący obecnie styl architektoniczny „Muratora”. Gros prywatnych domów w Polsce nie powstaje na bazie żadnej regionalnej tradycji, ich źródłem są jednorodne rozwiązania pochodzące $z$ łatwo dostępnego katalogu.

$\mathrm{Na}$ zakończenie tego wątku wspomnę o pewnej strategii, służącej w założeniu przezwyciężeniu napięcia między stylem międzynarodowym a kopiowaniem lokalności. To architektura parametryczna. Jeden z jej promotorów, Patrik Schumacher (2010), określił jej priorytety jako dążenie do wypracowania stanu, 
w którym wszystkie elementy będą zmienne w sposób ciągły, płynnie dostosowując się do siebie nawzajem, ale także do kontekstu lokalnego. Przy czym kontekst ów i myślenie o nim ma bardzo specyficzny charakter. Przykładem architektury parametrycznej jest projekt domu FabLab House, przygotowany przez projektantów z barcelońskiego Instytutu Zaawansowanej Architektury. Projekt sprowadza się do algorytmu zawartego w specjalnym programie komputerowym: po wprowadzeniu doń szerokości geograficznej przyszłej lokalizacji oraz sumy rocznych opadów generuje on kształt budynku. Wynik działania tego programu $\mathrm{w}$ najmniejszym nawet stopniu nie jest zależny od regionalnych, historycznych bądź kulturowych cech miejsca-regionu. Jedyną determinantą projektu są uwarunkowania klimatyczne.

\section{„RAMA” ZAMIAST IDIOMU}

Podobnie krytyczne stanowisko wobec paradygmatu myślenia w kategoriach regionalnych odnajdziemy we współczesnym dyskursie historii sztuki. Negatywnym punktem odniesienia jest $\mathrm{w}$ tym przypadku jeden $\mathrm{z}$ prekursorów antropologii, Friedrich Ratzel. Sam określający się jako „antropogeograf”, był promotorem i twórcą stanowiska determinizmu geograficznego. Dowodził, że można wykazać łączność między danym regionem a zamieszkującymi go ludźmi i ich kulturą. W kulturze tej miałyby bowiem odbijać się cechy lokalnego krajobrazu, jednocześnie mieszkańcy danego regionu mieliby kształtować ów krajobraz w zgodzie $z$ własną duchowością.

Ekspresją tych założeń jest opus magnum Ratzela, czyli trzytomowe Völkerkunde publikowane w latach 1895-1901. Każdy z przedstawianych tam ludów jest przypisany konkretnemu regionowi. Ratzel przekonywał, że nie istnieje coś takiego jak „wyłącznie czysty krajobraz naturalny” (Naturlandschaft). Przykładem był dla niego choćby krajobraz niemiecki. Dobitnie przekonuje o tym sama okładka pracy Deutschland. Einführung in die Heimatkunde (1907), ukazująca sielski górski krajobraz, z błękitnym okiem jeziora i takimż nieboskłonem.

Istotne jest to, że teorie tego badacza przyczyniły się do ukształtowania dwudziestowiecznego rozumienia pojęcia Heimat, a potem także jego pochodnych, takich jak Heimatkunstbewegung („ruch sztuki ojczyźnianej”), Heimatschutz („ochrona ojczyzny”) i Heimatmalerei („malarstwa ojczyźnianego”). Na tej bazie ugruntowało się myślenie w kategoriach Kunstgeographie, czyli geografii artystycznej, do niedawna jeszcze dominujące w głównym nurcie historii sztuki. Na czym polegała logika Kunstgeographie? Na tym, że obecność i działalność artystów w danej przestrzeni regionalnej sprowadzano do ahistorycznej wizji odwzorowywanego przez nich „wspaniałego krajobrazu”, metafizycznego pojęcia genius loci czy wreszcie rzekomo naturalnie definiowanej aktywności mieszkańców (co znalazło odzwierciedlenie także w ideologii „Blut und Boden”). W monografii malarza Georga Wichmanna cały jeden rozdział poświęcono geologicznemu opisowi Karkonoszy (Wichmann 1996); z kolei syntetyczne opracowanie 
karkonoskiego życia artystycznego nosi znamienny tytuł Wspaniały krajobraz. Artyści i kolonie artystyczne... (Bździach 1999). Romantyczne malarstwo pejzażowe utożsamiono tym samym ze specyficznym $-\mathrm{z}$ ducha Ratzelowskim niemieckim „odczuciem natury”.

Przyznanie geografii i regionowi prymatu nad sztuką i talentem w ostatnich latach znalazło się w ogniu krytyki. Miejsce tradycyjnie rozumianej i aplikowanej geografii artystycznej zaczęły zajmować koncepcje z nurtu „nowej geografii artystycznej” i „geohistorii sztuki” (DaCosta Kauffman 2004). Na najbardziej podstawowym poziomie chodzi tu o to, by do kategorii geograficznych dodać także czynnik czasu, czyli kontekst historyczny, a w konsekwencji również polityczny. Ważne stanowisko w tej debacie zajął Piotr Piotrowski. Dawna geografia artystyczna była dla niego powielaniem spetryfikowanego obrazu miejsc hegemonicznych i miejsc tej hegemonii pozbawionych; mówiąc inaczej, bazowaniem na kliszy centrum-peryferie. Logika była w takich przypadkach nieubłagana: „Każde centrum ma tendencję do totalitaryzacji, widzi siebie jako ognisko, od którego rozchodzą się promienie" (Piotrowski 2005, s. 17). Dla badacza sztuki państw dawnego Bloku Wschodniego uderzające było choćby zastosowanie geografii artystycznej podczas bońskiej wystawy „Europa, Europa” z 1994 roku. Czeski kubizm pokazano tam obok rosyjskiego konstruktywizmu, choć obu nic nie łączyło (poza kliszą myślową rodem z centrum). Co więcej, nie ujawniono żadnych odniesień do sztuki francuskiej, rzeczywiście konstytutywnych dla czeskich i rosyjskich awangardzistów. Tego rodzaju zabiegi, bardzo rozpowszechnione, wymagają sięgnięcia, jak twierdzi Piotrowski, po krytyczną geografię artystyczną. W pierwszej kolejności winna ona zająć się odkrywaniem stosunków władzy zapisanych w przestrzeni. Chodzi o badanie relacji między miejscami i regionami, prowadzące do zastąpienia statycznej geografii sztuki modelami dynamicznymi. Jeśli nadal mówi się tutaj o tożsamości, to już bez odniesienia do wyżej wspomnianej metafizyki miejsca i jej korelatów.

Wskazałem wcześniej na paradoks większego podobieństwa regionów wydobycia ropy naftowej niż ziem leżących, w sensie przestrzennym, tuż obok siebie. W kontekście uwag o „awangardzie w cieniu Jałty” dostrzec można zbliżone zjawisko: kubistyczna Praga bliższa była przecież „zachodniemu” Paryżowi niż „wschodniej”, „braterskiej” Bratysławie czy Warszawie. Błędem byłoby jednak powtarzanie poglądów Ratzela o kluczowym znaczeniu dyfuzji z centrum na peryferie. Piotrowski twierdzi, że zasadnicze znaczenie ma rama interpretacyjna, jaką posłużymy się do zrozumienia relacji między sztuką a miejscem/regionem. O ile Ratzelowski krytyk sztuki może określić dzieła Mirosława Bałki i Ilyi Kabakova mianem powtórzenia idiomatyki artystycznej Zachodu, o tyle "geohistoryk" sztuki włączy w akt ich rozumienia indywidualną mitologię domu w Otwocku, nagrobnego granitu i szarego mydła (Bałka) oraz kulturowe praktyki zamieszkiwania w radzieckich mieszkaniach komunalnych (Kabakov).

Postulowana „rama” obejmuje zatem coś o wiele bardziej złożonego niż region definiowany poprzez krajobraz czy ducha miejsca. Wymaga uwzględnienia 
kontekstów politycznych, światopoglądowych i historycznych, a także dynamiki wielokierunkowych trajektorii, bez podziału na domniemane centra i rzekome peryferie. $\mathrm{W}$ tym sensie zatem przestaje istnieć region jako autonomiczny idiom determinujący sztukę, działalność artystyczną i praktyki interpretacyjne. Sprowadzenie serii pejzażowych obrazów Otto Dixa, namalowanych w latach 1941-1942 w Karkonoszach, wyłącznie do emanacji regionu i jego genius loci byłoby aktem okradania artysty z bogactwa jego sztuki. Ważniejsze były bowiem subtelne i wielopoziomowe gry, jakie Dix podejmował z tradycją wielkiej sztuki europejskiej, niż domniemane gry z tradycją określonego regionu (Rome-Dzida 2013, s. 431-488).

\section{POZA „KULTURĘ” REGIONU}

Akhil Gupta i James Ferguson notowali w 1992 roku: „W teorii antropologicznej w nikłym stopniu obecna jest samoświadomość kwestii przestrzeni, co jest zaskakujące jak na dyscyplinę, której centralnym obrzędem przejścia są badania terenowe, której urok bierze się z odkrywania tego, co odległe i której funkcja krytyczna zdaje się polegać na zestawianiu radykalnie odmiennych form egzystencji" (Gupta, Ferguson 2004, s. 266). Zauważyli, że w naukach społecznych przedstawianie przestrzeni opiera się na metaforyce pęknięcia i rozdzielenia. Odrębność społeczeństw i kultur jest wszak rutynowo wpisywana $\mathrm{w}$,naturalną" nieciągłość przestrzeni, na przykład w mapach świata jako zbioru „krajów” albo kultur narodowych, z których każda jest zakorzeniona w swoim własnym (i właściwym) miejscu. Bazą tego typu myślenia jest założenie o izomorfizmie przestrzeni, miejsca i kultury.

Liisa Malkki (1992) określiła to założenie jako naturalizm etnologiczny. Polega on na ujmowaniu jako naturalnego związku między jednolitą kulturową grupą — plemieniem, ludem, etnosem - a ,jej” terytorium. Inną odmianą tego naturalizmu jest naturalizm narodowy, czyli myślenie $\mathrm{w}$ kategoriach naturalnego związku między obywatelami państw a ich ojczystymi terytoriami. Ostatecznym efektem stosowania i utrzymywania obu tych naturalizmów jest trwający bezustannie proces wytwarzania różnicy kulturowej bądź (w odmiennej idiomatyce) polityka inności. „Tam” i „tutaj”, obczyzna i ojczyzna, nasz region i obcy region - są w tym kontekście pojęciami-przekładniami, napędzającymi cały system.

Gupta i Ferguson zgłosili wobec tego założenia trzy zasadnicze wątpliwości: co z ludźmi zamieszkującymi granicę i stale przemieszczającymi się między odrębnymi terytoriami; co z różnicami kulturowymi wewnątrz wydzielonego terytorium, w obliczu faktu, że wielokulturowość to „kiepska” reakcja na utratę przez kultury oparcia w konkretnych miejscach; co wreszcie $z$ hybrydycznymi kulturami ery postkolonialnej. Ludzie zawsze byli bardziej mobilni, a tożsamości mniej niezmienne, niż sądzono. Zjawiska te wyraźnie nasiliły się w dobie globalizacji świata, w której deterytorializacja i wykorzenienie są powszechne. 
Jako pierwsi tych realiów doświadczają imigranci, emigranci, uchodźcy, wysiedleńcy; w odmienny sposób ich ekspresją jest odradzający się przedrewolucyjny Teheran w Los Angeles. Nowy regionalizm z pewnością najwięcej zawdzięcza dyskursom mniejszościowym i teoriom z nurtu postkolonialnego. Regionalne i lokalne narracje o tożsamości, różnicy i przestrzeni postrzega się w kategoriach strategii emancypacyjnych, przybierających postać krytycznej reakcji na dwie wielkie narracje: narodową z jednej strony oraz globalizacyjną z drugiej.

Nie ulega wątpliwości, że przestrzeń ma znaczenie — zdaniem cytowanych wcześniej antropologów zadanie krytycznie nastawionego badacza polega jednak na tym, by temu znaczeniu nadać wymiar polityczny. Próby odpowiedzi na powyższe kwestie nieuchronnie prowadzą do przyjęcia, że „topografii udało się ukryć topografię władzy [...] przestrzenie zawsze były ze sobą powiązane hierarchicznie, a nie naturalnie rozdzielone" (Gupta, Ferguson 2004, s. 269). Współcześnie antropologowie muszą być wyczuleni na fakt, że badani przez nich ludzie nie są automatycznie i naturalnie zakotwiczeni w przestrzeni. Co więcej, problemem staje się to, w jaki sposób te przestrzenie - regiony, państwa, a nawet kontynenty ${ }^{2}$ - są tworzone, stabilizowane, wyobrażane, kontestowane bądź odrzucane. Dystans między bogaczami w Londynie i Bombaju okazuje się bowiem mniejszy niż dystans dzielący różne klasy społeczne w tym samym mieście. Fizyczna lokalizacja i fizyczne terytorium - dotychczas jedyne narzędzia służące do odwzorowania różnicy kulturowej - obecnie są zbyt anachroniczne, statyczne i zachowawcze.

„Obszary różnicy” ulegają ponadto przesunięciom, stwierdza Homi K. Bhabha (2010, s. XXXVI). Pryzmat różnic klasowych, płciowych i kulturowych w miejscach „przepływów” oraz „transferów” jest dość łatwy do zidentyfikowania. Dynamika zjawiska owych przesunięć wymaga jednak czegoś więcej. Chodzi o to, że samo pojęcie jednorodnej kultury narodowej (wspólnoty etnicznej, plemiennej, regionalnej) oraz przypisanego jej terytorium należy głęboko przemyśleć. Kulturowa i etniczna „czystość” jest bowiem do uzyskania jedynie w wyniku czystek, ludobójstwa, przesiedleń i fiksacji na punkcie granic.

Postępowanie w kategoriach „topografii władzy” nie musi być, zaznaczmy, adekwatne jedynie do kultur hybrydycznych czy postkolonialnych. Jego zręby dają się z powodzeniem odnieść także do realiów polskich; co więcej, taka aplikacja pozwala na fuzję przywołanych wyżej ustaleń architektów i historyków sztuki. Można mianowicie przyjąć, że we współczesnej Polsce (a zapewne także w innych krajach europejskich) silniej zarysowują się różnice na osi centrum-peryferie niż na osiach wyznaczanych przez regiony i wiązaną z nimi politykę

\footnotetext{
${ }^{2}$ Już w 1957 roku japoński etnolog Tadao Umesao opublikował zbiór esejów, w którym podważył sens pojęcia „Azja” i dualizmu Wschód-Zachód. Dowodził, że nie istnieją żadne „mocne” różnice - kulturowe, językowe, religijne, etniczne ani środowiskowe - które wyraźnie oddzielałyby Azję od Europy. Co więcej, na obu krańcach tych kontynentów występuje wiele paralelizmów historycznych i kulturowych (Umesao 2003).
} 
różnicy. Jednym z czynników sprawczych jest oczywiście kondycja ekonomiczna, wyrażająca się we wciąż nierównomiernej dystrybucji kapitału, lokalizowanego w centrach i dużych ośrodkach aglomeracyjnych. Jeśli uświadomimy sobie, że łacińskie regio pochodzi od czasownika regere, czyli rządzić, to można uznać, że etymologia staje się synonimem kulturowego i ekonomicznego sensu.

\section{KONFLIKTY TOPOGRAFII}

Regiony — jak zaznaczyłem — są bez przerwy tworzone, stabilizowane, wyobrażane, kontestowane bądź odrzucane. Doskonałym przykładem wielokrotnych transformacji topografii regionalnej jest Francja (Dayries, Dayries 1978). Odbywająca się tam transformacja statusu regionów, ich definicji i kompetencji władz regionalnych jak w soczewce skupia najbardziej istotne idee dwudziestowiecznego europejskiego regionalizmu. Od XVIII wieku ścierały się tam ze sobą dwa przeciwne wektory: centralizacja i regionalizacja. Kolejne reformy administracyjne ogniskowały się właśnie wokół tych kluczowych napięć: relacji między wyborami lokalnymi a krajowymi, redystrybucji dochodów państwa, a także regionalnej autonomii ekonomicznej, kulturowej, językowej, edukacyjnej itp.

Wielkim laboratorium tworzenia i stabilizowania regionu był Śląsk po 1922 roku oraz tzw. Ziemie Odzyskane po 1945 roku, najpierw przedmiot czystek etnicznych, potem przesiedleń, a następnie wytwarzania ich historii, tożsamości, kultury i architektury. Zaledwie powiatowe i prowincjonalne pruskie Kattowitz szybko starano się przeobrazić w stolicę najbogatszego regionu Drugiej Rzeczypospolitej. W ogłaszanych wówczas konkursach architektonicznych znajdował się znaczący zapis: „styl gotycki wyklucza się” (Wysokiński 2013, s. 25). Gotyk i neogotyk kojarzył się z niemieckością, którą chciano przezwyciężyć sięgając do stylu palazzo in fortzezza, popularnego wśród polskiej magnaterii. Kwintesencją polskości i przywracania jej wielkości stała się budowa ultranowoczesnej siedziby Muzeum Sląskiego. Przed wejściem doń zaprojektowano figurę Bolesława Chrobrego (pierwszego króla, który przyłączył Śląsk do „macierzy”), konny posąg marszałka Józefa Piłsudskiego, a elewację miały zdobić wizerunki Ślązaczek w strojach ludowych.

Konieczność nacjonalistycznego „odzyskania” regionów powróciła po drugiej wojnie światowej. Odbudowa starych miast we Wrocławiu, Gdańsku czy Opolu $\mathrm{w}$ istocie winna być postrzegana właśnie w tych kategoriach: uwydatnianie barokowych elementów miało wszak ewokować imperialną, siedemnastowieczną Rzeczpospolitą. Były to zatem przedsięwzięcia nade wszystko nacjonalistyczne, a nie regionalistyczne. Uwagi Gupty i Fergusona jedynie to potwierdzają. Kilka dekad później zupełnie poważnie pisze się o tożsamości Lubuszanina, lubuskiej ludowości i lubuskiej odmienności i bada je. O ile potrafimy już krytycznie zanalizować ideologiczny program Heimatkunstbewegung albo Heimatmalerei czy funkcjonowanie niemieckiego Muzeum Towarzystwa Karko- 
noskiego (pierwszy skansen na Śląsku), a także skorelowanego z nim wynalezienia śląskiej szopki bożonarodzeniowej oraz ludowego stroju zachełmiańskiego (Rome-Dzida 2013, s. 495), o tyle podobne krytyczne stanowiska wobec nacjonalistycznego ustanawiania regionów przez państwo polskie nadal są lekcją do odrobienia. „Naturalna” topografia wciąż zbyt mocno przysłania w tym przypadku topografię władzy politycznej i militarnej.

Mimo zarysowanych wyżej ostrych głosów krytycznych polityka regionalna jest oczywiście uprawiana nadal, choć być może niektóre jej mechanizmy — przynajmniej w Polsce - mają bardziej dyskretny charakter. Znaczące jest to, że w dyskursie oficjalnym coraz bardziej odchodzi się od poziomu polityki do poziomu marketingu i promocji. Region coraz częściej rozpatruje się jako produkt turystyczny bądź nawet w kategoriach atrakcyjnego „brandu”. Kilka lat temu od wewnątrz przyglądałem się działaniom, podczas których region potraktowano jako względnie autonomiczny organizm ekonomiczno-społeczno-kulturowy, z całym dobrodziejstwem myślenia o jego rzekomej „naturalności”. Zostałem bowiem powołany do zespołu eksperckiego „Foresight Regionalny dla Wielkopolski”. Dalsze partie tekstu będą odnosić się do doświadczeń zdobytych podczas pracy $\mathrm{w}$ tym zespole.

\section{ZŁOTA ERA FORESIGHTU}

Foresight znaczy dosłownie tyle, co „patrzeć w przód”, „przewidywać przyszłość”, „prognozować”. W języku polskim nie ma adekwatnego odpowiednika tego terminu, stosuje się zatem powszechnie termin anglojęzyczny. W idiomie współczesnej humanistyki i zarządzania odnosi się on do pewnej metody prognozowania, polegającej na szeroko zakrojonych debatach, angażujących wszystkie segmenty społeczeństwa: władzę publiczną, przedstawicieli przedsiębiorców, mediów, nauki, organizacji czwartego sektora itd. Idzie tutaj zatem zarówno o działalność badawczą, jak i społeczną; tyleż o charakterze poznawczym, co obywatelskim. Najważniejsze w foresighcie nie jest dokładne prognozowanie tego, co nadejdzie. Chodzi raczej o przygotowywanie do zmian, otwieranie na przyszłe perspektywy i horyzonty. Kluczowe jest krytyczne myślenie o przyszłości, a także angażowanie maksymalnie wielu podmiotów społecznych, co odbywa się w duchu demokracji uczestniczącej.

Foresight zdefiniowany w powyższy sposób po raz pierwszy zastosowano w Japonii w roku 1970 (Martin 2002, s. 9-10). Rząd japoński poszukiwał wtedy sposobów na zwiększenie konkurencyjności swojej gospodarki, a badania prognostyczne miały za zadanie wskazanie tych dziedzin, które mogłyby stać się atutem na arenie międzynarodowej (dla porządku dopowiedzmy, że wzorowano się na projektach prowadzonych w latach sześćdziesiątych przez instytucje federalne i duże firmy na terenie Stanów Zjednoczonych). To właśnie wtedy sięgnięto po znak rozpoznawczy foresightu, jakim są badania Delphi, czyli zasięganie opinii na konkretny temat wśród zaproszonych ekspertów, de- 
cydentów itp. Istotne jest nie tylko zdobycie opinii, ale także uwrażliwienie uczestników badania na zmianę własnych poglądów i zapatrywań. Ostatecznym wynikiem owego specyficznego okrąłego stołu jest prognoza wynegocjowana wspólnie, z uwzględnieniem partykularnych stanowisk. Prognoza taka ma następnie funkcjonować jako drogowskaz określający kierunek rozwoju. W modelowym scenariuszu foresightowy konsensus winien stać się samospełniającym się proroctwem, za które odpowiedzialni są wszyscy uczestnicy badań Delphi.

W 1983 roku foresight — jako zbiór technik badawczych i prognostycznych — został zdefiniowany przez prestiżowy i wpływowy zespół Science and Technology Policy Research z uniwersytetu w Sussex. W tym ujęciu rychło stał się ważnym narzędziem budowania nowej polityki rozwoju (Martin 2010). Lider tego zespołu badawczego Ben R. Martin (we współpracy z Johnem Irvinem) tak oto ujął strategię badawczą foresightu: to proces zogniskowany na systematycznych próbach uchwycenia długoterminowej przyszłości na poziomie nauki, techniki, gospodarki i społeczeństwa, realizowany w celu rozpoznania obszarów mogących przynieść największe korzyści gospodarcze i społeczne. Zdaniem tych badaczy foresight jest współcześnie jedyną możliwą odpowiedzią na konflikt w ustalaniu priorytetów rozwojowych, pozwala bowiem na wypracowywanie mechanizmów radzenia sobie ze złożonością i współzależnościami, integrując przy tym zróżnicowane segmenty społeczeństwa, gospodarki nauki itp. (Irvine, Martin 1984, s. 3). Podobnego sformułowaniu użył w 1996 roku Luke Georghiou, według którego foresight polega na systematycznej ocenie technologicznego i społecznego rozwoju z punktu widzenia korzyści wzmacniających konkurencyjność, a także dobrobyt i jakość życia.

W początkowym okresie foresight był stosowany i odnoszony do przestrzeni technologii i gospodarki. Okazało się jednak, że korzystne jest wykorzystanie tej metody także do prognozowania $\mathrm{w}$ innych dziedzinach życia zbiorowego. Badaczem, który uzasadnił sens takiej aplikacji, był Joseph F. Coates (1985). Sugerował on, że foresight to proces dochodzenia do zrozumienia sił, które kształtują przyszłość, i jako taki winien mieć kluczowe znaczenie w budowaniu decyzji politycznych oraz dalekosiężnych planów rozwojowych.

Lata dziewięćdziesiąte XX wieku dowiodły, że działania w Japonii i Wielkiej Brytanii wywołały efekt kuli śnieżnej. Badania o profilu foresightowym zaczęto prowadzić kolejno w wielu krajach: Stany Zjednoczone (1982), Republika Federalna Niemiec (1985), Australia (1989), Korea Południowa (1991), Holandia, Nowa Zelandia (1992), Wielka Brytania, Francja, Włochy (1994), Indie (1995), Kanada, Indonezja (1996), Tajlandia, Finlandia, Węgry (1997) itd. Raporty będące wynikiem tych badań stały się dokumentami określającymi priorytety rozwojowe poszczególnych państw, społeczeństw i regionów.

Bez przesady można powiedzieć, że przełom XX i XXI wieku okazał się erą foresightu. Próbując wskazać kluczowe czynniki, które sprawiły, że metoda ta stała się tak popularnym narzędziem kształtowania polityki, należy uwzględnić 
przede wszystkim istotność globalizacji (we wszystkich jej wymiarach), formowanie się społeczeństw informacyjnych, budowanie gospodarek opartych na wiedzy, a także przekonanie o słuszności idei zrównoważonego rozwoju. Sieć European Foresight Monitoring Network odnotowała w roku 2009 realizację ponad 1900 projektów foresightowych, wliczając w to projekty ponadnarodowe (Unia Europejska), krajowe (m.in. zakończony w Polsce w maju 2009 r. „Narodowy Program Foresight Polska 2020”), regionalne oraz branżowe.

\section{FORESIGHT WIELKOPOLSKI}

„Foresight Regionalny dla Wielkopolski” rozpoczął się w roku 2009 i jak na razie jest najbardziej rozbudowanym ze wszystkich dotychczasowych regionalnych projektów tego typu w kraju. Intensywne prace w jego ramach trwały trzy lata (dokładnie 27 miesięcy), w ten czy inny sposób angażując kilka tysięcy Wielkopolan. Najważniejszym rezultatem okazały się trzy scenariusze rozwojowe, wariantowo odnoszące się do przyszłości Wielkopolski aż do roku 2030.

Kluczowym elementem przedsięwzięcia „Foresight Regionalny dla Wielkopolski" były badania metodą delficką. Przeprowadzono je w roku $2011 \mathrm{w}$ dwóch rundach. Do udziału zaproszono 1284 osoby. Reprezentowały one różne środowiska: pracodawców i związki zawodowe, samorządowców i działaczy kultury, edukacji i nauki, organizacje zawodowe i pozarządowe (stowarzyszenia, fundacje, izby rzemieślnicze). Zaproszone do badania osoby pochodziły ze wszystkich części regionu, zarówno tych o charakterze wielkomiejskim, jak i małomiasteczkowym oraz wiejskim. Ankietowanie miało charakter anonimowy i tym różniło się od standardowych sondaży, że uczestnicy dwukrotnie odpowiadali na te same pytania. Co ważne, po pierwszej rundzie badania otrzymywali informację na temat odpowiedzi udzielonych przez wszystkie osoby w rundzie pierwszej. Zabieg ten miał służyć wypracowaniu kompromisu między odmiennymi poglądami, skorygowaniu ich i porównaniu z innymi spojrzeniami. Ponadto zastosowano metodę STEEP oraz krzyżową analizę wpływów. Mówiąc najogólniej, STEEP polega na rozpoznaniu i uwzględnieniu najważniejszych zewnętrznych czynników rozwoju, czyli uwarunkowań społecznych, technologicznych, ekonomicznych, ekologicznych oraz polityczno-prawnych, które mogły mieć pozytywny bądź negatywny wpływ na prognozowany rozwój Wielkopolski. Dzięki metodzie krzyżowej analizy wpływów możliwe było uwzględnienie wzajemnych oddziaływań wymienionych czynników.

Wszystkie badania prowadzono w pięciu głównych obszarach osadzonych w określonym kontekście. Były to:

— kapitał społeczny (w odniesieniu do poziomu konkurencyjności i rozwoju społeczeństwa obywatelskiego);

— tożsamość regionalna (w kontekście stabilności społecznej, wysokiej kultury gospodarowania oraz pragmatyzmu myślenia i działania, traktowanych jako cechy tej tożsamości); 
— postawa wobec „nowych” i „nowego” (przyjęto tezę, że zmniejszanie się poziomu tradycjonalizmu winno wydatnie zwiększać akceptację wobec „nowych" ludzi, idei, wzorców zachowań, wartości itp.);

- przywództwo regionalne (rola partnerstwa, różnych form komunikowania i przejrzystość działań jako ważnych instrumentów zarządzania, a także obecność w regionie skutecznych strategii wyłaniania nowych talentów przywódczych);

- konkurencyjna współpraca (co zapewne brzmi jak zaskakujący oksymoron, jednak zostało uznane za narzędzie pozwalające na konkurowanie regionalnych marek na rynku globalnym).

Wnioski z badań wskazywały, że wszystkie powyższe tezy zostały uznane przez Wielkopolan za możliwe do realizacji. Nie był to jednak, warto zauważyć, optymizm bezgraniczny, gdyż przyjmowano, że jest to możliwe dopiero w dłuższej perspektywie czasowej, głównie w okresie 2020-2030. Szybko okazało się również, że powszechne jest postrzeganie Wielkopolski na tle innych regionów w bardzo pozytywny, korzystny sposób. Jako najbardziej istotne atuty regionu wskazywano solidność gospodarczą, skorelowaną ściśle z tożsamością regionalną, będącą jej gwarantem. Bez wątpienia zatem biorący udział w badaniach $\mathrm{w}$ większości zgadzali się z tym, że istnieje coś takiego jak pozytywny etos Wielkopolan, którego residuum jest regionalna tożsamość. Dostrzegano także ważkość innych kwestii: poziomu zaufania społecznego (na każdym szczeblu wspólnego życia), inicjatyw społecznych, wspierania ich przez władze regionalne oraz edukacji wspierającej postawy obywatelskie.

Ostatecznym - najbardziej pożądanym — wynikiem „Foresightu Regionalnego dla Wielkopolski" było opracowanie trzech scenariuszy rozwoju regionu. Zważywszy na naszkicowane wcześniej uwarunkowania - tak globalne, jak i lokalne - zbudowano trzy scenariusze, uwzględniające trzy odmienne trajektorie przyszłości Wielkopolan i ich małej ojczyzny ${ }^{3}$. Były to: (1) scenariusz wzrostu, optymizmu i wyłonienia się regionalnej „Doliny Krzemowej”; (2) scenariusz umiarkowanego realizmu, trwania nierówności społecznych i powrotu centrali, czyli Poznania; (3) scenariusz stagnacji, przetrwania w kategoriach ekonomicznych i społecznych oraz powrotu do tradycji rozumianej jako stagnacja.

To, co najbardziej interesujące w myśleniu w kategoriach regionu, pokazują dane dotyczące odrębności Wielkopolan i Wielkopolski. Okazało się, że mieszkańcy regionu, oceniani przez „obcych”, uchodzą za osoby raczej zamknięte, konserwatywne, niechętnie nastawionych do „nowych” - ludzi, wartości, pomysłów czy smaków. Co to oznacza w praktyce? Choćby fakt, że w sektorze kreatywnym (Poznań i obszar metropolitarny) większość stanowią osoby urodzone w regionie, a ponad $90 \%$ to absolwenci lokalnych uczelni. Replikuje się

${ }^{3}$ Szczegółowe scenariusze można znaleźć na: WWW.foresightwielkopolska.pl. 
zatem proces obserwowany w pozostałych krajach dawnego Bloku Wschodniego, który w tym zakresie nadal silnie odróżnia je od Europy Zachodniej. Gdy weźmiemy pod uwagę, że wszelkie dostępne raporty światowe wskazują na to, że hermetyczność środowisk twórczych skutkuje małą dynamiką ich rozwoju, to konstatacja taka nie jest pozytywna.

\section{REGION TWORZY MIESZKAŃCÓW}

Kontrapunktem $\mathrm{w}$ tej sytuacji są wypowiedzi osób pochodzących $\mathrm{z}$ innych krajów, które zdecydowały się osiąść w regionie i podjąć tutaj pracę. Zdecydowanie przeważa wśród nich opinia o tym, że Poznań i Wielkopolska są otwarte i tolerancyjne, co pozytywnie wyróżnia je wśród pozostałych regionów naszego kraju. Do nader rzadkich incydentów - w oczach pytanych — należą akty wrogości. Bardzo ważna dla obcokrajowców jest wysoka jakość życia w regionie, różnorodność oferty kulturalnej oraz rozrywkowej, wytrzymująca, ich zdaniem, porównanie $z$ innymi europejskimi metropoliami i regionami (Stryjakiewicz, Męczyński, Stachowiak 2009, s. 29-32).

„Foresight Regionalny dla Wielkopolski” przede wszystkim ujawnił silne zróżnicowanie regionu, jak również konieczność pogodzenia się ze stanem pluralizmu kulturowego i społecznego. W pewnych miejscach niekwestionowanym autorytetem jest nadal parafialny ksiądz, gdzie indziej funkcję taką pełni lider samorządu albo organizacji pozarządowej. Jedni Wielkopolanie cenią nowinki obyczajowe i szybko je akceptują (włoskie pesto jako potrawa na wigilijnym stole), inni są silnie przywiązani do swojej identyfikacji, najczęściej oznaczającej jakiś rodzaj konserwatyzmu i rezerwy wobec tego, co nowe. Część osób traktuje jako innowacyjne wysyłanie życzeń świątecznych przy użyciu elektronicznych komunikatorów (telefon komórkowy, komputer podłączony do sieci internetowej), inni natomiast postrzegają w ten sposób wypisywanie kart pocztowych (praktyka coraz rzadsza, a więc innowacyjna) ${ }^{4}$.

Doświadczenia związane $z$ foresightem rozpatrywanym na tle dyskursu regionalnego uświadamiają kilka rzeczy. Po pierwsze, na poziomie dyskursu władz samorządowych region funkcjonuje jako naturalna, historycznie warunkowana i legitymizowana jednostka podziału przestrzeni. Region to rzeczywistość par excellence, nie wymagająca uzasadnień, ale raczej scenariuszy rozwojowych nakierowanych na przyszłość. Wątpliwości dotyczące „kontekstu”, „ramy” czy też „kultury” regionu są w tym dyskursie niewidoczne albo minimalizowane. Warto zauważyć, że uwzględnienie tych wątpliwości podważyłoby podstawy systemu dystrybucji władz lokalnych, które bez umocowania w regionach musiałyby szukać kompletnie nowego zakorzenienia. Po drugie, myślenie w kategoriach regionu, regionalnej tożsamości i regionalnej przynależności

${ }^{4}$ Więcej na ten temat zob. Kuligowski 2013. 
okazuje się obecnie wtórną potoczną racjonalizacją. Badania foresightowe pokazują, że Wielkopolanie bez trudu rozpoznają samych siebie w kliszach określonego „etosu” i systemu wartości. Sytuacja wygląda tak, że to właśnie region jest postrzegany jako gwarant trwania pewnych praktyk i norm, które bez tego czynnika rozpłynęłyby się $\mathrm{w}$ amalgamacie „bezregionalności”. Nie tyle zatem mieszkańcy tworzą region, ile region tworzy swoich mieszkańców. Po trzecie, „Foresight Regionalny dla Wielkopolski” jest kolejnym mocnym dowodem na to, że istnieje ogromny rozdźwięk między dyskursem krytycznym współczesnej humanistyki a dyskursem aplikacyjnym współczesnej polityki. W tej mierze nie należy się spodziewać poważniejszych zmian, może jedynie regresu do myślenia z czasów Ratzela.

\section{BIBLIOGRAFIA}

Bhabha Homi K., 2010, Miejsca kultury, tłum. Tomasz Dobrogoszcz, Wydawnictwo Uniwersytetu Jagiellońskiego, Kraków.

Bździach Klaus (red.), 1999, Wspaniały krajobraz. Artyści i kolonie artystyczne w Karkonoszach XX wieku, Gesellschaft für interregionalen Kulturaustausch, Berlin-Jelenia Góra.

Coates Joseph F., 1985, Foresight in Federal Government Policymaking, „Futures Research Quarterly”, nr 1.

DaCosta Kauffman Thomas, 2004, Toward a Geography of Art, The University of Chicago Press, Chicago.

Dayries Jean-Jacques, Dayries Michèle, 1978, La regionalization, Presses Universitaires de France, Vendôme.

Frampton Kenneth, 1983, Towards a Critical Regionalism: Six Points for an Architecture of Resistance, w: Hal Foster (red.), The Anti-Aesthetic: Essays on Postmodern Culture, Bay Press, Port Townsend.

Georghiou Luke, 1996, The UK Technology UK Program Foresight, „Futures”, t. 28(4), s. 359-377.

Gupta Akhil, Ferguson James, 2004, Poza „kulturę”: przestrzeń, tożsamość i polityka różnicy, tłum. Jerzy Giebułtowski, w: Marian Kempny, Ewa Nowicka (red.), Badanie kultury. Elementy teorii antropologicznej. Kontynuacje, Wydawnictwo Naukowe PWN, Warszawa.

Ibelings Hans, 1998, Supermodernism: Architecture in the Age of Globalization, NAI Publishers, Rotterdam.

Irvine John, Martin Ben R., 1984, Foresight in Science, Pinter Publishers, London.

Koolhaas Rem, 1995 [1993], Bigness or the Problem of Large, w: Rem Koolhaas, Bruce Mau, S, M, L, $X L$, Monacelli Press, New York.

Koolhaas Rem, 1999, A Conversation between Rem Koolhaas and Sarah Whiting, „Assemblage”, nr 40, s. $68-79$.

Kuligowski Waldemar, 2013, Wielkopolska roku 2030. Czy Foresight prawdę nam mówi?, „Przegląd Wielkopolski", nr 2 (100).

Le Corbusier, 2012, W stronę architektury, tłum. Tomasz Swoboda, Centrum Architektury, Warszawa.

Malkki Liisa, 1992, National Geographic: The Rooting of Peoples and the Territorialization of National Identity among Scholars and Refugees, „Cultural Anthropology”, nr 1.

Martin Ben R., 2002, Technology Foresight in a Rapidly Globalizing Economy, w: International Practice in Technology Foresight, United Nations Publications, Vienna.

Martin Ben R., 2010, The Origins of the Concept of 'Foresight' in Science and Technology: An Insider's Perspective, „Technological Forecasting and Social Change”, t. 77 (9), s. 1438-1447. 
Moćko Wojciech, 2013, Wieżowiec, sala koncertowa i przeszczepianie. Jak Rem Koolhaas mierzy się z regionalizmem?, „Rzut. Kwartalnik Architektoniczny”, nr 2, s. 6-11.

Piotrowski Piotr, 2005, Awangarda w cieniu Jałty. Sztuka w Europie Środkowo-Wschodniej w latach 1945-1989, Rebis, Poznań.

Ratzel Friedrich, 1885-1901, Völkerkunde, Bibliographisches Institut, Leipzig-Wien, 3 t.

Ratzel Friedrich, 1907, Deutschland. Einführung in die Heimatkunde, Grunow, Leipzig.

Rome-Dzida Agata, 2013, Niemieccy artyśsi w Karkonoszach w latach 1880-1945. Przyczynek do badań nad Heimatkunst, Ad Rem, Jelenia Góra.

Schumacher Patrik, 2010, The Autopoiesis of Architecture, John Wiley\&Sons, London.

Stryjakiewicz Tadeusz, Męczyński Michał, Stachowiak Krzysztof, 2009, Poznan as a Creative Region: The Views of High-Skilled Employees, Managers and Transnational Migrants, University of Amsterdam, Amsterdam.

Umesao Tadao, 2003, An Ecological View of History: Japanese Civilization in the World Context, thum. B. Cary, Trans Pacific Press, Melbourne.

Wichmann Hans, 1996, Georg Wichmann 1876-1944. Der Maler des Riesengebirges und sein Kreis, W. G. Korn, Würzburg.

Wysokiński Kacper, 2013, Regionalizm i polityka na Górnym Śląsku w latach 1922-1939, „Rzut. Kwartalnik Architektoniczny”, nr 2.

Zaera Alejandro, 1999, Finding Freedoms: Converstaions with Rem Koolhaas. Interview by Alejandro Zaera, w: OMA/Rem Koolhaas 1987-1998, El Croquis Editorial, Madrid.

'FUCK THE CONTEXT!'

CRITICAL REGIONAL DISCOURSE IN THE CONTEXT OF FORESIGHT STUDIES

\section{Summary}

This article is an attempt at a critical and interdisciplinary analysis of the idea of the region. The author reviews and summarizes critical views of the idea in the discourses of architecture (Frampton, Koolhaas, Ibelings), art history (DaCosta, Kauffman, Piotrowski), and social anthropology (Gupta, Ferguson, Malkki, Bhabha). He then focuses on the example of the contemporary discourse on power, in which the concept of 'region' still functions in the form of implicit premises about the naturalness of differences and territorial and cultural divisions. The example is analyzed through the findings of the research project 'Regional Foresight for Wielkopolska' (2009-2011). The author's conclusion points to the great dissonance between the discourse of modern humanities and the applied discourse of contemporary policy (including regional policy).

\section{Key words / słowa kluczowe}

region / region; critical regionalism / regionalizm krytyczny; critical artistic geography / krytyczna geografia artystyczna; foresight studies / badania foresight; Wielkopolska 